\title{
AN INTEGRATED DEMATEL-IF-TOPSIS METHODOLOGY FOR LOGISTICS CENTERS' LOCATION SELECTION PROBLEM: AN APPLICATION FOR ISTANBUL METROPOLITAN AREA
}

\author{
Cihan UYANIK ${ }^{1}$, Gulfem TUZKAYA ${ }^{*}$, Zeynep Tuğçe KALENDER ${ }^{3}$, Senay OGUZTIMUR ${ }^{4}$ \\ ${ }^{1-3}$ Dept of Industrial Engineering, Marmara University, Istanbul, Turkey \\ ${ }^{4}$ Dept of City and Regional Planning, Ylldiz Technical University, Istanbul, Turkey
}

Received 22 May 2018; revised 23 November 2018, 27 February 2019; accepted 13 April 2019;

first published online 19 March 2020

\begin{abstract}
Logistics Centers (LCs) are among the most important facilities for rapid, cost effective, environmental friendly and secure logistics services to the urban logistics problems. Finding proper locations to LCs has an important effect on their success. In this study, LCs' location selection problem for Istanbul Metropolitan area is investigated. Istanbul is a leading city of Turkey in many categories including various industries, import/export amounts, transportation infrastructure and population density. However, industrialization and urbanization have introduced numerous problems to Istanbul. New projects are continuously being announced for the problems of metropolis, however, they may also bring new problems if they are not punctiliously planned and applied. Hence, in this study, it is aimed to propose a systematic Multi-Criteria Decision-Making (MCDM) approach for the LCs' location selection problem of Istanbul. In this approach, an integrated DEcision-MAking Trial and Evaluation Laboratory (DEMATEL) and Intuitionistic Fuzzy (IF) Technique for Order Preference by Similarity to Ideal Solution (TOPSIS) method is utilized. DEMATEL is used to analyse the decision criteria and IF-TOPSIS is used to evaluate candidate locations for LCs. Considering the vagueness inherent to this decision-making problem, IF sets are used for the evaluation process. Results are compared with the results of IF-VIKOR (VIše Kriterijumska Optimizacija kompromisno Rešenje - multi-criteria optimization and compromise solution) technique.
\end{abstract}

Keywords: logistics centers, DEMATEL, intuitionistic fuzzy sets, TOPSIS, location selection.

\section{Notations}

Abbreviations:

AHP - analytical hierarchy process;

AHP-GP - analytical hierarchy process and goal programming;

DEMATEL - decision-making trial and evaluation laboratory;

$\mathrm{DM}$ - decision maker;

IF - intuitionistic fuzzy;

IF-TOPSIS - IF technique for order preference by similarity to ideal solution;

IFS - IF set;

IF-VIKOR - IF više kriterijumska optimizacija kompromisno rešenje (multi-criteria optimization and compromise solution);

IFWA - IF weighted averaging;

LC - logistics center;
MCDM - multi-criteria decision-making;

NRD - network relations diagram;

NRM - network relationship map;

TCDD - Turkish State Railway;

TOPSIS - technique for order preference by similarity to ideal solution.

Variables and functions:

A1 - alternative 1 (Halkalı);

A2 - alternative 2 (Yeşilbayır);

A3 - alternative 3 (Tuzla);

A4 - alternative 4 (Çorlu);

$\mathrm{A}^{+}-$IF positive-ideal solution;

$\mathrm{A}^{-}$- IF negative-ideal solution;

$C_{i}-$ closeness coefficient.

\footnotetext{
${ }^{*}$ Corresponding author. E-mail: gulfem.tuzkaya@marmara.edu.tr
} 


\section{Introduction}

Logistics sector is a rapidly developing sector in parallel with the industrial and commercial improvements. Today, to survive in a competitive environment, having a proper logistics strategy, which responds to the needs of industry and commerce is essential for the companies. Under these circumstances, LCs are considered as one of the most important facilities producing solutions for the urban logistics problems. According to the European Logistics Platforms Association (Europlatforms 2015), which is an association of Transport and LCs all over Europe, LC is a center located in a pre-defined area for performing and organizing the activities such as transportation, logistics and the distribution services, etc. The concept of logistic centers had first appeared in USA together with the industrial development. In Japan, the concept was applied in order to decrease the level of traffic jam, environmental problems, energy and work force costs (Koldemir et al. 2009). In 1960s, initial LCs had been established in Europe and since 1980s the number of LCs has increased rapidly (Kapros et al. 2005). Today, in the borders of European Union, there are 240 LCs. In Turkey, the first LC has been founded by TCDD and it became active in 2007. Currently, 7 active LCs are active, 6 LCs are at their construction stage and 7 LCs are at their project stage in Turkey.

In the literature, as a reflection of the emerging number of application projects, an increasing number of studies have been prepared for the problems related to the LCs. According to the Uyanik et al. (2018), literature for LCs location selection problem can be classified into three categories: MCDM techniques, mathematical programming based studies and integrated approaches of MCDM techniques and mathematical models. Naturally, location selection problems require the consideration of multiple criteria and MCDM techniques are the most widely used techniques for this research area. In most of the MCDM studies for this problem, initial step is the determination of decision criteria for the evaluation of alternatives. It is a well-known fact that determination of evaluation criteria and their weights is very important for decision-making processes since it directly effects the final ranking. For this purpose, researchers applied different approaches to obtain more accurate criteria and their weights and tried to generate hybrid models via integrating different MCDM methodologies (Bamyacı, Tanyaş 2008; Kayikci 2010; Elgün, Elitaş 2011; Görgülü 2012; Elevli 2014; Chen et al. 2014; Demiroğlu, Eleren 2014; Peker et al. 2016). Literature review also revealed that some of the studies use two or more MCDM methodologies for the same problem and then compare the results to find the most appropriate methodology for the focused problem and decide the ranking (Can 2012; Yildirim, Önder 2014; Önden et al. 2018; Özceylan et al. 2016). AHP is the mostly used technique in the literature. Additionally, in most of the recent studies, fuzzy sets based approaches are implemented to reflect the vagueness inherent to the real life problems (Chen, Qu 2006; Wang, Liu 2007; Yu et al. 2009; Erkay- man et al. 2011; Li et al. 2011; Zalluhoğlu et al. 2014; Önden et al. 2018)

Mathematical programming based approaches are also used for logictics centers' location selection problem. In 1999, Taniguchi et al. (1999) proposed a vehicle routing and scheduling model and the dynamic traffic simulation model to find optimal size and location for public logistics terminals. Genetic algorithms are applied to find road network of the central area in Kobe City, Japan. Klapita and Švecová (2006) focused on uncertain costs and compared different solution methodologies for LCs location problem. Yang and Moodie (2011) generated a mathematical model to find location and size of logistics terminals and shopping centers in China with the objective function of total retail supply chain cost minimization. They also considered personal shopping trips. Aksoy and Özyörük (2015) proposed a linear programming and 0-1 integerprogramming model to evaluate 12 LCs locations, which are determined by TCDD. Bayraktutan and Özbilgin (2014) compared a classical model and a fuzzy model for an application from Turkey. The foreign trade volume, highway, seaway and airway freight traffic, transportation types of cities in Turkey were determined by using both the classical and the fuzzy logic method. Objective function of the model tries to minimize the total costs including LC establishment costs, operation management costs and transportation costs.

In some of the studies, MCDM techniques and mathematical models are integrated for LCs' location selection problem. Tomić et al. (2014) investigated convenient LC locations in the capital cities of the Balkan Peninsula by incorporating Greedy heuristic algorithm and AHP. Regmi and Hanaoka (2013) compared the results of AHP and combined AHP-GP methods for alternative location evaluations. The models were developed based on location models and public and private sector stakeholders evaluated them.

In this study, LCs' location selection problem is investigated by using an integrated MCDM approach. Different from the literature, Istanbul Metropolitan area is selected for the case study since it can be considered as a leading city of Turkey in many categories including various industries, import-export amounts, transportation infrastructure and population density. However, industrialization and urbanization have introduced numerous problems to Istanbul. New projects are continuously being announced for the problems of metropolis, however, they may also bring new problems if they are not punctiliously planned and applied. From this point of view, selecting a proper LC location is very important to reduce the amount of transport vehicles in Istanbul. Moreover, location of the LC may have an effect on the traffic, noise and environmental pollution levels. In addition, it is a well-known fact that selecting the proper location is as important as the other functions of LCs. In the current situation, there are two logistic centers in Istanbul, which controlled by TCDD: the first one located in Halkalı and is currently ac- 
tive, and the second one is located in Yeşilbayır and in the project stage. In this study, Halkalı, Yeşilbayır, Tuzla and Çorlu locations are evaluated for their convenience as LCs locations using the integrated DEMATEL and IF-TOPSIS methodology. During the criteria determination phase, a detailed literature review is conducted and also expert opinions are taken into consideration. Collected criteria are analysed and eliminated by applying DEMATEL. Criteria evaluation phase is conducted by experts from logistics sector, academy, civil society and governmental sector. As discussed previously, determination of the evaluation criteria is a vital step for decision-making problems. In this study, DEMATEL is used to determine final criteria list for analysis. The underlying reason of selecting DEMATEL is that it provides a great advantage on evaluating relationship among evaluation criteria; hence, it also provides insights for their elimination procedure. In addition, DEMATEL method enables to designate cause and affect group considering multiple criteria to analyse relationship among criteria and generate NRM (Tzeng, Huang 2011). Another critical point, which has a direct impact on the final ranking, is the selection of the proper method for criteria and alternatives evaluation process. In this study, IF-TOPSIS procedure is selected for the analysis since in the weight determination step; linguistic terms can be used to collect expert opinions. In many complex decision-making problems, the information provided by the DMs is insufficient and uncertain. For this reason, in the analysis of uncertainty inherent to the decisionmaking problems, fuzzy logic becomes one of the most preferred methods. IF sets can be considered as an extended version of the fuzzy set theory, which better models imperfect knowledge (Atanassov 1986) and become a useful solution tool to describe uncertain decision-making data fairly well. Criteria weights and alternative locations' ratings on the basis of criteria were calculated by using linguistic terms and IF numbers in IF-TOPSIS method. Results of the methodology is compared with the results of the IF-VIKOR approach. In the next section of this study, solution methodologies and the proposed approach are explained and in the second section, case study and its results are presented.

\section{Methodology}

In this study, an integrated DEMATEL and IF-TOPSIS methodology is used for LC location selection problem. This methodology starts with definition of the problem and the alternatives. Then, evaluation criteria are listed via conducting a comprehensive literature review and gathering expert opinions. DEMATEL methodology is used to determine final evaluation criteria based on the analysis of the relationship among criteria. Weight of each criteria is calculated by using linguistic terms based on the opinions of representing groups. As a final step, alternatives are ranked by applying IF-TOPSIS methodology.

\subsection{DEMATEL procedure}

DEMATEL method was developed by the Battelle Memorial Institute of Geneva Research Center in 1972. DEMATEL enable to designate cause and effect groups among multiple criteria to indicate relationship among criteria and generate NRM (Tzeng, Huang 2011). Steps of DEMATEL method are explained in Figure 1 (Tzeng, Huang 2011; Hori, Shimizu 1999; Tsai, Chou 2009).

\subsection{IF-TOPSIS procedure}

Fuzzy set theory definition was firstly proposed by Zadeh (1965) and defined a "membership function" with a value between zero and one. $A$ is a fuzzy set in $X$ :

$$
A=\left\{x, \mu_{A}(x) \mid x \in X\right\},
$$

where: $\mu_{A}: X \rightarrow[0,1]$ is a membership function of fuzzy set $A ; \mu_{A}(x)$ is degree of membership of $x$ in $A$ (Xu 2007; Szmidt, Kacprzyk 2000).

Almost fifteen years later then the fuzzy sets are firstly introduced by Zadeh (1965), Atanassov (1986) introduced IFS as an extension of fuzzy sets. In addition to the membership degree, non-membership degree is defined to offer a solution to the problem of vagueness. $A$ is an IFS in $X$ :

$$
A=\left\{x, \mu_{A}(x), v_{A}(x) \mid x \in X\right\},
$$

where:

$$
\begin{aligned}
& \mu_{A}: X \rightarrow[0,1] \text { and } v_{A}: X \rightarrow[0,1] ; \\
& 0 \leq \mu_{A}(x)+v_{A}(x) \leq 1 \\
& \text { for all } x \in X .
\end{aligned}
$$

Degree of membership and non-membership functions of IFS $A$ are indicated by $\mu_{A}(x), v_{A}(x)$. IFSs also have another value, $\pi_{A}(x)$ to define a degree of indeterminacy of $x$ to $A$ (Atanassov 1986) and it is called as intuitionistic index (Szmidt, Kacprzyk 2000) or hesitancy degree. $\pi_{A}(x)$ value indicates certainty of $x, x$ is considered more certain if $\pi_{A}$ has a small value. If $\pi_{A}$ has a big value, $x$ is considered as more uncertain (Shu et al. 2006).

$$
\begin{aligned}
& \pi_{A}(x)=1-\mu_{A}(x)-v_{A}(x) \\
& \text { and } 0 \leq \pi_{A}(x) \leq 1 \\
& \text { for all } x \in X .
\end{aligned}
$$

Let $A=\left\{A_{1}, A_{2}, \ldots, A_{m}\right\}$ be a set of $m$ alternatives and $C=\left\{C_{1}, C_{2}, \ldots, C_{n}\right\}$ be a set of $n$ criteria. Steps of IF-TOPSIS are given in Figure 2 (Boran et al. 2009; Joshi, Kumar 2014).

\section{Case study}

Istanbul Metropolitan area is selected for the case study since it can be considered as a leading city of Turkey in many categories including various industries, import-export amounts, transportation infrastructure and population density. In the current situation, there are two LCs (A1 Halkalı and A2 - Yeşilbayır) in Istanbul controlled by TCDD. 


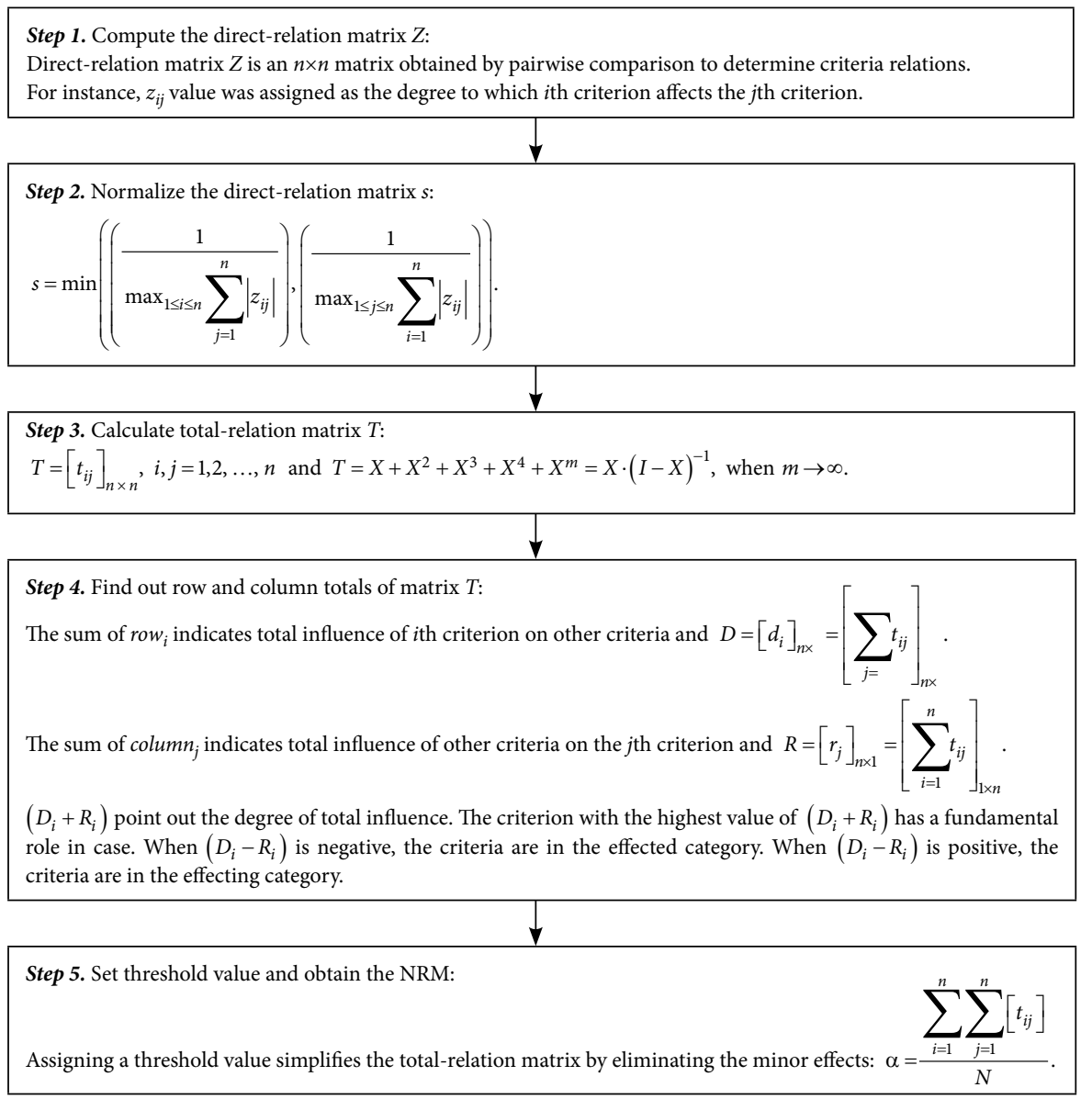

Figure 1. Steps of DEMATEL

While Halkalı is an active LC, Yeşilbayır is in its project stage. In this study, in addition to the A1 and A2 alternatives, considering the expert opinions, A3 and A4 (Tuzla and Çorlu) are also evaluated as candidate LC locations via the procedure given in Figure 3.

A literature review study on LCs' location selection problem has been carried out by Uyanik et al. (2018) to determine the evaluation criteria. Uyanik et al. (2018) listed the main and sub-criteria by reviewing publications and then prepared a criteria list. Then, 453 criteria are evaluated and classified into cost, cargo capacity/economic reflections, environment, location and social factor categories. At the final step, criteria, which are used less than 6 times was omitted and following this elimination process, 19 criteria are selected (Uyanik et al. 2018). In this study, among these 19 criteria, three of them are eliminated, namely: "proximity to an airport", "state subsidies", "safety and security". "Proximity to an airport" is eliminated, because, for this case, air transportation volume is at an ignorable level, while the criteria of "state subsidies" and "safety and security" are eliminated, because, alternative locations have similar characteristics for these aspects, hence, they are not distinctive. Final list of the selected criteria are given below:

- cost (C1);

- natural resources (C2);
- proximity to railroad system (C3);

- proximity to highway system (C4);

- proximity to city center (C5);

- proximity to harbour (C6);

- size (C7);

- suitability to enlargement (land) (C8);

- proximity to industrial zone (C9);

- macro-economic benefits/performance (C10);

- environmental impacts (C11);

- freight transport (C12);

- suitability to construction (topography, geography, ground structure) (C13);

- cost of construction process (C14);

- accessibility to labour pool (C15);

- transportation and logistics attractiveness (C16).

The action and reaction relations among the criteria are found by using DEMATEL technique. The question "How $i$ th criterion affects $j$ th criterion?" - is asked to the DMs and the responses are used to form direct-relation matrix $Z$. Following the steps of DEMATEL methodology, row and column totals of total-relation matrix are found as mentioned in Step 4 of the DEMATEL methodology (Figure 1) and shown in Table 1.

The threshold value is obtained as 0.06 by using the formula given in the Step 5 of the DEMATEL methodology (Figure 1) and NRD is found as shown in Figure 4. 


$$
\begin{aligned}
& \text { Step 1. Calculate the DMs' importance degrees: } \\
& l=\left\{l_{1}, l_{2}, \ldots, l_{l}\right\} \text { be a set of DM and } D_{k}=\left[\mu_{k}, v_{k}, \pi_{k}\right] \text { shows the IF number for } k \text { th DM's importance degree. The } k \text { th DM's weight: } \\
& \lambda=\frac{\mu_{k}+\pi_{k} \cdot\left(\frac{\mu_{k}}{\mu_{k}+v_{k}}\right)}{\sum_{k=1}^{l} \mu_{k}+\pi_{k} \cdot\left(\frac{\mu_{k}}{\mu_{k}+v_{k}}\right)}, \lambda_{k} \geq 0, k=1,2, \ldots, l \text { and } \sum_{k=1}^{l} \lambda_{k}=1 .
\end{aligned}
$$

$$
\begin{aligned}
& \text { Step 2. Construct aggregated IF decision matrix: } \\
& \text { IF decision matrix of each DMs is set as: } R^{(k)}=\left(r_{i j}^{(k)}\right)_{m \times n} \cdot \\
& \text { The weight of each DM is: } \lambda=\left\{\lambda_{1}, \lambda_{2}, \ldots, \lambda_{l}\right\} \text { and } \sum_{k=1}^{l} \lambda_{k}, \lambda_{k} \in[0,1] . \\
& \text { Aggregated IF decision matrix is generated by IFWA operator and shows the group decisions: } \\
& r_{i j}=I F W A_{\lambda}\left(r_{i j}^{(1)}, r_{i j}^{(2)}, \ldots, r_{i j}^{(l)}\right)=\lambda_{1} \cdot r_{i j}^{(1)} \oplus \lambda_{2} \cdot r_{i j}^{(2)} \oplus \lambda_{3} \cdot r_{i j}^{(3)} \oplus \ldots \oplus \lambda_{l} \cdot r_{i j}^{(l)} ; \\
& R_{i j}=\left[1-\prod_{k=1}^{l}\left(1-\mu_{i j}^{(k)}\right)^{\lambda_{k}}, \prod_{k=1}^{l}\left(v_{i j}^{(k)}\right)^{\lambda_{k}}, \prod_{k=1}^{l}\left(1-\mu_{i j}^{(k)}\right)^{\lambda_{k}}-\prod_{k=1}^{l}\left(v_{i j}^{(k)}\right)^{\lambda_{k}}\right], \\
& \text { where: } r_{i j}=\left(\mu_{A_{i}}\left(x_{j}\right), v_{A_{i}}\left(x_{j}\right), \pi_{A_{i}}\left(x_{j}\right)\right), i=1,2 \ldots, m, j=1,2, \ldots, n .
\end{aligned}
$$

\section{Step 3. Calculate the criteria weights:}

Let $w_{j}^{(k)}=\left[\mu_{j}^{(k)}, v_{j}^{(k)}, \pi_{j}^{(k)}\right]$ be an IF number. The elements of matrix provided by $k$ th DM. The criteria weights are obtained by using IFWA operator:

$w_{j}=I F W A_{\lambda}\left(w_{j}^{(1)}, w_{j}^{(2)}, \ldots, w_{j}^{(l)}\right)=\lambda_{1} \cdot w_{j}^{(1)} \oplus \lambda_{2} \cdot w_{j}^{(2)} \oplus \lambda_{3} \cdot w_{j}^{(3)} \oplus \ldots \oplus \lambda_{l} \cdot w_{j}^{(l)} ;$

$W_{j}=\left[1-\prod_{k=1}^{l}\left(1-\mu_{j}^{(k)}\right)^{\lambda_{k}}, \prod_{k=1}^{l}\left(v_{j}^{(k)}\right)^{\lambda_{k}}, \prod_{k=1}^{l}\left(1-\mu_{j}^{(k)}\right)^{\lambda_{k}}-\prod_{k=1}^{l}\left(v_{j}^{(k)}\right)^{\lambda_{k}}\right] ;$

$W=\left[w_{1}, w_{2}, w_{3}, \ldots, w_{j}\right], w_{j}=\left(\mu_{j}, v_{j}, \pi_{j}\right), j=1,2, \ldots, n$.

\section{Step 4. Construct aggregated weighted IF decision matrix:}

By using criteria weights and the aggregated IF decision matrix, aggregated weighted IF decision matrix is obtained by using the multiplication operator of IFSs; $R \otimes W=\left\{\left\langle x, \mu_{A_{i}}(x) \cdot \mu_{W}(x), v_{A_{i}}(x)+v_{W}(x)-v_{A_{i}}(x) \cdot v_{W}(x)\right\rangle \mid x \in X\right\}$.

\section{Step 5. Calculate the IF positive-ideal solution and IF negative-ideal solution:}

$A^{*}=\left(\mu_{A^{*} W}\left(x_{j}\right), v_{A^{*} W}\left(x_{j}\right)\right) ; A^{-}=\left(\mu_{A^{-} W}\left(x_{j}\right), v_{A^{-} W}\left(x_{j}\right)\right)$.

Step 6. Calculate the intuitionistic separation measure:

In this study, normalized Euclidean distance was preferred as separation measure:

$$
E D=\sqrt{\frac{1}{2} \cdot n \cdot \sum_{j=1}^{n}\left(\mu_{A}\left(x_{j}\right)-\mu_{B}\left(x_{j}\right)\right)^{2}+\left(v_{A}\left(x_{j}\right)-v_{B}\left(x_{j}\right)\right)^{2}+\left(\pi_{A}\left(x_{j}\right)-\pi_{B}\left(x_{j}\right)\right)^{2}} .
$$

$$
\begin{aligned}
& \text { Step 7. Calculate the relative closeness coefficients to the intuitionistic ideal solution: } \\
& C_{i^{*}}=\frac{S_{i^{-}}}{S_{i^{*}}+S_{i^{-}}} \text {, where: } 0 \leq C_{i^{*}} \leq 1 .
\end{aligned}
$$

Figure 2. Steps of IF-TOPSIS

The criteria C1, C2, C3, C4, C5, C6, C7, C8, C9 and C13, which have the positive $D_{i}-R_{i}$ values, are located in the category of the affecting criteria. On the other side, C10, C11, C12, C14, C15, C16, C17 criteria, which have negative $D_{i}-R_{i}$ values, are located in the category of the affected criteria. C10 and C14 with the lowest $D_{i}-R_{i}$ val- ues are eliminated and the remaining 14 criteria are used in IF-TOPSIS method.

IF-TOPSIS method is used to evaluate four alternative locations for LCs in Istanbul. The DMs are chosen as representative of logistics sector, civil society organization, academy and government/public groups and have 
different importance weights. As can be seen from Table 2, there is a slight difference between DMs' weights in terms of linguistic terms. It is found convenient to weight opinions of experts from logistics sector and academics slightly more than other DMs considering their studies on logistics and specifically on LCs. Their weights (Table 2) are found by the formula given in the Step 1 of IF-TOPSIS procedure (Figure 2) with respect to the linguistic terms given in Table 3.

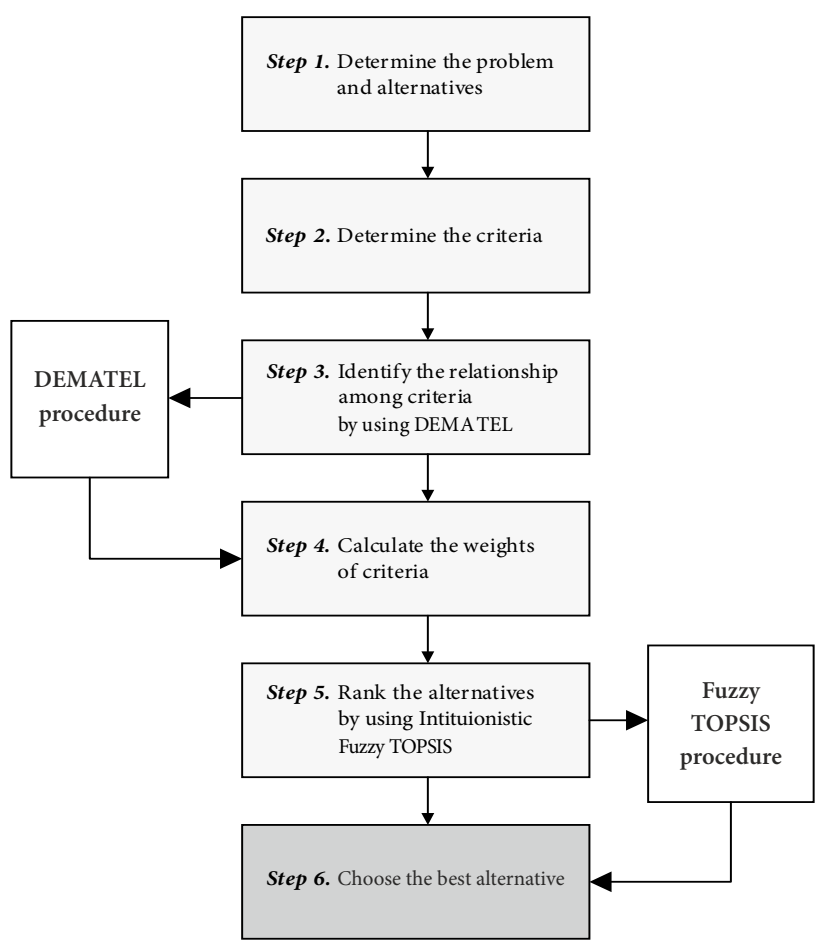

Figure 3. Steps of the proposed methodology

Table 1. Impacts on criteria

\begin{tabular}{|l|c|c|c|c|c|}
\cline { 2 - 6 } \multicolumn{1}{c|}{} & $D_{i}$ & $R_{i}$ & $D_{i}+R_{i}$ & $D_{i}-R_{i}$ & Status \\
\hline C1 & 1.930 & 1.806 & 3.736 & 0.124 & cause \\
\hline C2 & 1.040 & 0.814 & 1.854 & 0.226 & cause \\
\hline C3 & 0.954 & 0.457 & 1.411 & 0.497 & cause \\
\hline C4 & 0.870 & 0.519 & 1.389 & 0.351 & cause \\
\hline C5 & 1.456 & 0.503 & 1.959 & 0.953 & cause \\
\hline C6 & 1.200 & 0.435 & 1.635 & 0.765 & cause \\
\hline C7 & 1.073 & 0.861 & 1.934 & 0.212 & cause \\
\hline C8 & 0.958 & 0.928 & 1.886 & 0.030 & cause \\
\hline C9 & 0.986 & 0.367 & 1.353 & 0.619 & cause \\
\hline C10 & 0.497 & 1.700 & 2.197 & -1.203 & effect \\
\hline C11 & 0.760 & 1.373 & 2.133 & -0.613 & effect \\
\hline C12 & 1.164 & 1.520 & 2.684 & -0.356 & effect \\
\hline C13 & 0.837 & 0.732 & 1.569 & 0.105 & cause \\
\hline C14 & 0.419 & 1.169 & 1.588 & -0.750 & effect \\
\hline C15 & 0.634 & 0.895 & 1.529 & -0.261 & effect \\
\hline C16 & 0.686 & 1.382 & 2.068 & -0.696 & effect \\
\hline
\end{tabular}

DMs are requested to evaluate the alternative locations with respect to their performance on the determined criteria set by using linguistic terms given in Table 4 . Aggregated IF decision matrix (Step 2 of IF-TOPSIS procedure given in Figure 2) is formed by using DMs' evaluations on each criterion.

DMs evaluate the criteria by using the linguistic terms given in Table 4 and the formula given in the Step 3 of IFTOPSIS procedure is used (Figure 2) to find the weights. By using criteria weights and the aggregated IF decision matrix, aggregated weighted IF decision matrix is obtained by using the multiplication operator of IFSs as shown in Step 4 of the IF-TOPSIS procedure. In Step 5, IF positiveideal solution and IF negative-ideal solution values are calculated. In this study, normalized Euclidean distance was preferred as separation measure and $S_{i^{*}}$ and $S_{i^{-}}$are obtained in Step 6. As a final stage, Step 7 is implemented to find relative closeness coefficients to the intuitionistic ideal solution. Final scores are presented in Table 5.

Finally, ranking of the alternatives is obtained as A4 (Corlu) > A3 (Tuzla) > A1 (Halkalı) > A2 (Hadımköy). Evaluation result of Çorlu is very close to its nearest alternative, Tuzla. In addition, evaluation results of last two (Halkalı and Hadımköy) alternatives are very close to each other.

To compare the results of IF-TOPSIS approach, IFVIKOR methodology is also applied for the same problem. For the comparison, IF-VIKOR is selected, because, it has a similar structure with IF-TOPSIS. VIKOR methodology is based on an aggregation function presenting closeness to the ideal solution as in TOPSIS. However, they are different in some aspects. In TOPSIS, chosen alternative is the alternative with the highest relative closeness coefficient, which is calculated based on distances from negative-ideal and positive-ideal solutions. In VIKOR, the best alternative is the closest one to the ideal solution and it is generally the highest ranked alternative. Opricovic and Tzeng (2004) stated in their study that the main difference between mentioned methodologies is their aggregation approaches. Results of the IF-TOPSIS and IF-VIKOR methods are presented in Table 6.

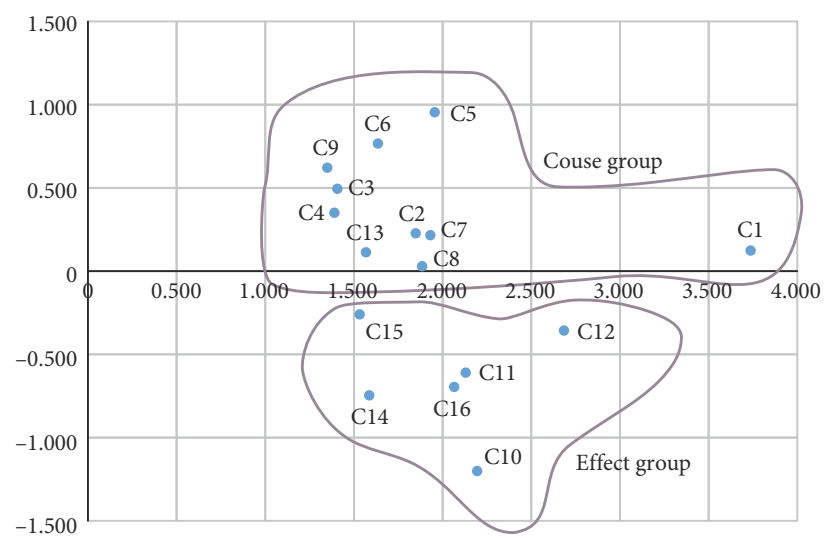

Figure 4. NRD 
Table 2. Importance of DMs

\begin{tabular}{|c|l|l|c|}
\hline ID & \multicolumn{1}{|c|}{ Representing group } & \multicolumn{1}{|c|}{ Linguistic term } & Weight \\
\hline DM1 & logistics sector & very important (VI) & 0.2725 \\
\hline DM2 & civil society organization & important (I) & 0.2275 \\
\hline DM3 & academy & very important (VI) & 0.2725 \\
\hline DM4 & government / public & important (I) & 0.2275 \\
\hline
\end{tabular}

Table 3. Linguistic terms for criteria and the DMs weight evaluation (Boran et al. 2009)

\begin{tabular}{|l|c|}
\hline \multicolumn{1}{|c|}{ Linguistic terms } & IFNs \\
\hline Very important (VI) & $(0.90,0.10)$ \\
\hline Important (I) & $(0.75,0.20)$ \\
\hline Medium (M) & $(0.50,0.45)$ \\
\hline Unimportant (U) & $(0.35,0.60)$ \\
\hline Very Unimportant (VU) & $(0.10,0,90)$ \\
\hline
\end{tabular}

Table 4. Linguistic terms for alternative evaluation (Boran et al. 2009)

\begin{tabular}{|l|c|}
\hline \multicolumn{1}{|c|}{ Linguistic terms } & IFNs \\
\hline Extremely good (EG) & {$[1.00,0.00]$} \\
\hline Very very good (VVG) & {$[0.90,0.10]$} \\
\hline Very good (VG) & {$[0.80,0.10]$} \\
\hline Good (G) & {$[0.70,0.20]$} \\
\hline Medium good (MG) & {$[0.60,0.30]$} \\
\hline Fair (F) & {$[0.50,0.40]$} \\
\hline Medium bad (MB) & {$[0.40,0.50]$} \\
\hline Bad (B) & {$[0.25,0.60]$} \\
\hline Very bad (VB) & {$[0.10,0.75]$} \\
\hline
\end{tabular}

Table 5. Final scores for candidate locations

\begin{tabular}{|c|c|c|c|}
\cline { 2 - 4 } \multicolumn{1}{c|}{} & $S^{*}$ & $S^{-}$ & $C_{i^{*}}$ \\
\hline $\mathrm{A} 1$ & 0.0157 & 0.1035 & 0.86861 \\
\hline $\mathrm{A} 2$ & 0.0147 & 0.0796 & 0.84412 \\
\hline $\mathrm{A} 3$ & 0.0116 & 0.1762 & 0.93845 \\
\hline $\mathrm{A} 4$ & 0.0112 & 0.1942 & 0.94549 \\
\hline
\end{tabular}

Table 6. Comparison of final scores for candidate locations

\begin{tabular}{|c|c|c|}
\cline { 2 - 3 } \multicolumn{1}{c|}{} & IF-TOPSIS & IF-VIKOR \\
\cline { 2 - 3 } \multicolumn{1}{c|}{} & & $Q$ \\
\hline A1 & 0.86861 & 0.7895 \\
\hline A2 & 0.84412 & 0.5145 \\
\hline A3 & 0.93845 & 0.5000 \\
\hline A4 & 0.94549 & 0.1411 \\
\hline
\end{tabular}

In the VIKOR methodology, smaller VIKOR index $Q$ is better, thus, final ranking is obtained as $\mathrm{A} 4$ (Çorlu) $>$ A3 (Tuzla) > A2 (Hadımköy) > A1 (Halkalı). This result does not show a significant difference with the result of IF-TOPSIS. Only, the ranking of last two alternatives Halkalı and Hadımköy - switched in IF-VIKOR approach.
In addition, these two alternatives' evaluation values are found very close in the IF-TOPSIS methodology. This slight difference is an expected situation due to the applied approaches' dissimilarities explained previously.

As a conclusion, Çorlu is found as the best alternative in the proposed approach and the IF-VIKOR methodology. It is advantageous over other alternatives in many ways. A LC to be established in Çorlu would have lower fixed costs, larger size, and more flexibility of land expansion, closer to industrial zones and areas of consumption and more suitable to construction.

\section{Conclusions}

It is important that an established LC does not remain idle and public resources are not wasted. It depends mostly on the location of the LCs, hence, in this study, a twostage methodology is proposed to evaluate and determine their locations. The first stage is the determination of the evaluation criteria and alternative locations. In this study, after a literature review is performed, lists of criteria are determined, and then, this list is evaluated, eliminated and weighted. During the criteria evaluation process, they are divided in two groups - effect and cause group - by using DEMATEL and a NRD is created. At the final step of DEMATEL method, macro-economic benefit/performance and cost of construction process criteria are eliminated since they are highly affected by the other criteria.

In the second step of the study, alternative locations for a LC is determined. The most recent projects for Istanbul have been restricted to the province's boundaries. Because of the difficulty in deciding suitable locations for large industrial projects for Istanbul, neighbouring provinces like as Kocaeli and Tekirdağ have begun to attract more industry. These areas, even they are not located within Istanbul's provincial boundaries, share in a common economic space with Istanbul. For that reason, this study focused on this metropolitan area and Çorlu, Halkal, Tuzla and Hadımköy is considered as the alternatives for LCs.

In deploying IF-TOPSIS, opinions of four expert groups from the logistic sector, civil society, the civil service and academia are taken. Weights of the criteria and possible locations' ratings for each evaluation criteria were determined by using linguistic term scale and their IF numbers. After the IF-TOPSIS procedure implemented, based on found final ranking, Çorlu is selected as the best location among considered alternatives. To compare the results of the proposed methodology, IF-VIKOR method is applied and same alternative location is found proper. Çorlu's position in comparison with other alternatives proves the importance of lower costs.

In this study, Istanbul Metropolitan area is examined and a logistic center location for this area is determined. However, it is planned to use this proposed model for the evaluation of different locations in Turkey in the future studies. In the evaluation of different locations, new criteria can be added to the model considering the characteristics and the requirements of the region and then 
DEMATEL method should be repeated to achieve the final criteria list. Additionally, different multi-criteria decisionmaking approaches can be applied to the same problem and results of the proposed model can be compared.

\section{References}

Aksoy, O.; Özyörük, B. 2015. The importance of freight villages: an implementation in TCDD, Applied Mathematical Modelling 39(19): 6043-6049. https://doi.org/10.1016/j.apm.2015.01.034

Atanassov, K. T. 1986. Intuitionistic fuzzy sets, Fuzzy Sets and Systems 20(1): 87-96.

https://doi.org/10.1016/S0165-0114(86)80034-3

Bamyacı, M.; Tanyaş, M. 2008. Organize lojistik bölgesi yer seçimi problemi için bir çok ölçütlü karar verme modeli: AHPSAW, in Mersin Sempozyumu, 19-22 kasım 2008, Mersin, Türkiye. (in Turkish).

Bayraktutan, Y.; Özbilgin, M. 2014. Türkiye'de illerin lojistik merkez yatirim düzeylerinin bulanik mantik yöntemiyle belirlenmesi, Erciyes Üniversitesi İktisadi ve İdari Bilimler Fakültesi Dergisi 43: 1-36. https://doi.org/10.18070/euiibfd.67041 (in Turkish).

Boran, F. E.; Genç, S.; Kurt, M.; Akay, D. 2009. A multi-criteria intuitionistic fuzzy group decision making for supplier selection with TOPSIS method, Expert Systems with Applications 36(8): 11363-11368. https://doi.org/10.1016/j.eswa.2009.03.039

Can, A. M. 2012. Çok Kriterli Karar Verme Teknikleri İle Samsun Lojistik Köyü Yerinin Belirlenmesi. Yüksek Lisans Tezi. Erciyes Üniversitesi, Türkiye. 158 s. (in Turkish).

Chen, K.-H.; Liao, C.-N.; Wu, L.-C. 2014. A selection model to logistic centers based on TOPSIS and MCGP methods: the case of airline industry, Journal of Applied Mathematics 2014: 470128. https://doi.org/10.1155/2014/470128

Chen, Y.; Qu, L. 2006. Evaluating the selection of logistics centre location using fuzzy MCDM model based on entropy weight, in 2006 6th World Congress on Intelligent Control and Automation, 21-23 June 2006, Dalian, China, 7128-7132. https://doi.org/10.1109/WCICA.2006.1714468

Demiroğlu, Ş.; Eleren, A. 2014. Küresel lojistik köyleri ve Türkiye'de kurulmasi planlanan lojistik köy bölgelerinin ÇKKV yöntemleriyle belirlenmesi, Dumlupınar Üniversitesi Sosyal Bilimler Dergisi - Dumlupinar University Journal of Social Sciences 42: 189-201. (in Turkish).

Elevli, B. 2014. Logistics freight center locations decision by using fuzzy-PROMETHEE, Transport 29(4): 412-418. https://doi.org/10.3846/16484142.2014.983966

Elgün, M. N.; Elitaş, C. 2011. Yerel, ulusal ve uluslararası taşıma ve ticaret açısından lojistik köy merkezlerinin seçiminde bir model önerisi, Celal Bayar Üniversitesi Sosyal Bilimler Dergisi 9(2): 630-645. (in Turkish).

Erkayman, B.; Gundogar, E.; Akkaya, G.; Ipek, M. 2011. A fuzzy TOPSIS approach for logistics center location selection, Journal of Business Case Studies 7(3): 49-55. https://doi.org/10.19030/jbcs.v7i3.4263

Europlatforms. 2015. Corporate Presentation. The European Logistics Platforms Association, Europlatforms E.E.I.G. 65 p. Available from Internet: http://www.europlatforms.eu/wpcontent/uploads/2016/01/Corporate-Presentation-2015-Europlatforms-Final_20151229.pdf

Görgülü, H. 2012. Lojistik Köyler ve Konya Uygulaması. Yüksek Lisans Tezi. Bahçeșehir Üniversitesi, Türkiye. 144 s. (in Turkish).
Hori, S.; Shimizu, Y. 1999. Designing methods of human interface for supervisory control systems, Control Engineering Practice 7(11): 1413-1419.

https://doi.org/10.1016/S0967-0661(99)00112-4

Joshi, D.; Kumar, S. 2014. Intuitionistic fuzzy entropy and distance measure based TOPSIS method for multi-criteria decision making, Egyptian Informatics Journal 15(2): 97-104. https://doi.org/10.1016/j.eij.2014.03.002

Kapros, S.; Panou, K.; Tsamboulas, D. A. 2005. Multicriteria approach to the evaluation of intermodal freight villages, Transportation Research Record: Journal of the Transportation Research Board 1906: 56-63. https://doi.org/10.1177/0361198105190600107

Kayikci, Y. 2010. A conceptual model for intermodal freight logistics centre location decisions, Procedia - Social and Behavioral Sciences 2(3): 6297-6311.

https://doi.org/10.1016/j.sbspro.2010.04.039

Klapita, V.; Švecová, Z. 2006. Logistics centers location, Transport 21(1): 48-52. https://doi.org/10.3846/16484142.2006.9638041

Koldemir, B.; Çanci, M.; Gönüler, E. 2009. Büyük ölçekli kent planlamasında lojistik köyler, in İzmir Ulaşım Sempozyumu, 8-9 Aralık 2009, İzmir, Türkiye, 457-464. (in Turkish).

Li, Y.; Liu, X.; Chen, Y. 2011. Selection of logistics center location using axiomatic fuzzy set and TOPSIS methodology in logistics management, Expert Systems with Applications 38(6): 7901-7908. https://doi.org/10.1016/j.eswa.2010.12.161

Opricovic, S.; Tzeng, G.-H. 2004. Compromise solution by MCDM methods: a comparative analysis of VIKOR and TOPSIS, European Journal of Operational Research 156(2): 445-455. https://doi.org/10.1016/S0377-2217(03)00020-1

Önden, İ.; Acar, A. Z.; Eldemir, F. 2018. Evaluation of the logistics center locations using a multi-criteria spatial approach, Transport 33(2): 322-334. https://doi.org/10.3846/16484142.2016.1186113

Özceylan, E.; Erbaş, M.; Tolon, M.; Kabak, M.; Durğut, T. 2016. Evaluation of freight villages: a GIS-based multi-criteria decision analysis, Computers in Industry 76: 38-52. https://doi.org/10.1016/j.compind.2015.12.003

Peker, I.; Baki, B.; Tanyas, Ar, I. M. 2016. Logistics center site selection by ANP/BOCR analysis: a case study of Turkey, Journal of Intelligent \& Fuzzy Systems 30(4): 2383-2396. https://doi.org/10.3233/IFS-152007

Regmi, M. B.; Hanaoka, S. 2013. Location analysis of logistics centres in Laos, International Journal of Logistics Research and Applications: a Leading Journal of Supply Chain Management 16(3): 227-242.

https://doi.org/10.1080/13675567.2013.812194

Shu, M.-H.; Cheng, C.-H.; Chang, J.-R. 2006. Using intuitionistic fuzzy sets for fault-tree analysis on printed circuit board assembly, Microelectronics Reliability 46(12): 2139-2148. https://doi.org/10.1016/j.microrel.2006.01.007

Szmidt, E.; Kacprzyk, J. 2000. Distances between intuitionistic fuzzy sets, Fuzzy Sets and Systems 114(3): 505-518. https://doi.org/10.1016/S0165-0114(98)00244-9

Taniguchi, E.; Noritake, M.; Yamada, T.; Izumitani, T. 1999. Optimal size and location planning of public logistics terminals, Transportation Research Part E: Logistics and Transportation Review 35(3): 207-222. https://doi.org/10.1016/S1366-5545(99)00009-5

Tomić, V.; Marinković, D.; Marković, D. 2014. The selection of logistic centers location using multi-criteria comparison: case study of the Balkan Peninsula, Acta Polytechnica Hungarica 11(10): 97-113. 
Tsai, W.-H.; Chou, W.-C. 2009. Selecting management systems for sustainable development in SMEs: a novel hybrid model based on DEMATEL, ANP, and ZOGP, Expert Systems with Applications 36(2): 1444-1458.

https://doi.org/10.1016/j.eswa.2007.11.058

Tzeng, G.-H.; Huang, J.-J. 2011. Multiple Attribute Decision Making: Methods and Applications. CRC Press. 352 p.

Uyanik, C.; Tuzkaya, G.; Oğuztimur, S. 2018. A literature survey on logistics centers' location selection problem, Sigma Journal of Engineering and Natural Sciences - Sigma Mühendislik ve Fen Bilimleri Dergisi 36(1): 141-160.

Wang, S.; Liu, P. 2007. The evaluation study on location selection of logistics center based on fuzzy AHP and TOPSIS, in 2007 International Conference on Wireless Communications, Networking and Mobile Computing, 21-25 September 2007, Shanghai, China, 3779-3782. https://doi.org/10.1109/WICOM.2007.935

$\mathrm{Xu}$, Z. 2007. Intuitionistic fuzzy aggregation operators, IEEE Transactions on Fuzzy Systems 15(6): 1179-1187. https://doi.org/10.1109/TFUZZ.2006.890678

Yang, Z. Z.; Moodie, D. R. 2011. Locating urban logistics terminals and shopping centres in a Chinese city, International Journal of Logistics Research and Applications: a Leading Journal of Supply Chain Management 14(3): 165-177. https://doi.org/10.1080/13675567.2011.609159

Yildirim, B. F; Önder, E. 2014. Evaluating potential freight villages in Istanbul using multi criteria decision making techniques, Journal of Logistics Management 3(1): 1-10.

Yu, X.; Zhang, X.; Mu, L. 2009. A fuzzy decision making model to select the location of the distribution center in logistics, in 2009 IEEE International Conference on Automation and Logistics, 5-7 August 2009, Shenyang, China, 1144-1147. https://doi.org/10.1109/ICAL.2009.5262593

Zadeh, L. A. 1965. Fuzzy sets, Information and Control 8(3): 338-353. https://doi.org/10.1016/S0019-9958(65)90241-X

Zalluhoğlu, A. E.; Aracioğlu, B.; Bozkurt, S. 2014. Lojistik köy kurulumunun lojistik hizmet sağlayıcılar açısından değerlendirilmesi: İzmir örneği, Ege Stratejik Araştırmalar Dergi 5(2): 81-104. https://doi.org/10.18354/esam.39733 (in Turkish). 